\title{
Maastricht University Graduate Surveys 2012
}

Citation for published version (APA):

Levels, M., \& Meng, C. M. (2012). Maastricht University Graduate Surveys 2012. ROA. ROA Fact Sheets No. 003 https://doi.org/10.26481/umarof.2012003

Document status and date:

Published: 01/01/2012

DOI:

10.26481/umarof.2012003

Document Version:

Publisher's PDF, also known as Version of record

\section{Please check the document version of this publication:}

- A submitted manuscript is the version of the article upon submission and before peer-review. There can be important differences between the submitted version and the official published version of record.

People interested in the research are advised to contact the author for the final version of the publication, or visit the DOI to the publisher's website.

- The final author version and the galley proof are versions of the publication after peer review.

- The final published version features the final layout of the paper including the volume, issue and page numbers.

Link to publication

\footnotetext{
General rights rights.

- You may freely distribute the URL identifying the publication in the public portal. please follow below link for the End User Agreement:

www.umlib.nl/taverne-license

Take down policy

If you believe that this document breaches copyright please contact us at:

repository@maastrichtuniversity.nl

providing details and we will investigate your claim.
}

Copyright and moral rights for the publications made accessible in the public portal are retained by the authors and/or other copyright owners and it is a condition of accessing publications that users recognise and abide by the legal requirements associated with these

- Users may download and print one copy of any publication from the public portal for the purpose of private study or research.

- You may not further distribute the material or use it for any profit-making activity or commercial gain

If the publication is distributed under the terms of Article $25 \mathrm{fa}$ of the Dutch Copyright Act, indicated by the "Taverne" license above, 
Tuastricht University in Learning!

Research Centre for Education and the Labour Market | ROA

\section{Maastricht University graduate surveys 2012}

\section{ROA Fact Sheet}

ROA-F-2012/3

Researchcentrum voor Onderwijs en Arbeidsmarkt | ROA Research Centre For Education and the Labour Market / ROA 


\section{Maastricht University graduate surveys 2012}

How successful is Maastricht University in preparing its students for the labour market? What career paths are Maastricht University alumni taking in the short and medium term, and how do they look back on their time in Maastricht? This fact sheet presents the most important results of a 2012 survey amongst three cohorts of Maastricht University alumni. The first cohort graduated in the academic year 2009-2010 (these respondents were interviewed in 2OII-20I2), the second cohort graduated in the academic year 2005-2006 (six years prior to the 2012 survey), the third cohort graduated in the academic year 2000-200I (II years prior to the 2012 survey).,

\section{Position in the labour market}

Six to eleven years after graduation, around $95 \%$ of the Maastricht University alumni are in paid work. Of those not involved in paid work, a small percentage was at the moment of the survey searching for work and, all disciplines taken together, only $2 \%$ of graduates of 2005 2006 and $2 \%$ of graduates of $2000-200$ r reported to be out of the labour force. Important reasons for inactivity include participating in further education or to be taking care of children or relatives. Focussing on those currently searching for work, Table I gives a more detailed overview of graduates' unemployment rates by cohort and faculty. On average, $8 \%$ of alumni of the $2009-2010$ cohort, $3 \%$ of the $2005-2006$ cohort and $2 \%$ of the $2000-200$ I cohort are unemployed. ${ }^{3}$ It should be noted that a substantial part of this unemployment rate is frictional (i.e. the time-period between two jobs). Therefore, involuntary unemployment does not seem to be a problem amongst Maastricht University graduates. A possible exception to this conclusion are Arts and Social Sciences graduates five years after graduation. Graduates from this faculty also appear to have the most trouble making the transition to the labour market, as the

I. Of the 2009-20I0 cohort, 1777 respondents were approached, of whom $29 \%$ responded, and $25 \%$ filled in a complete form. For the $2005-2006$ cohort, of the 2390 alumni we approached, 2264 could be reached. Of these $37 \%$ participated in the survey, and $31 \%$ filled out a complete form. Of the alumni from the 2000-200I cohort, of the 1327 alumni we approached, I270 could be reached. Of these alumni, 34\% responded, with $28 \%$ completing the survey.

2. The reader should keep in mind that the mix of studies offered by Maastricht University the respondents graduated from might vary between the three cohorts. In particular, the youngest cohort consists of graduates from Master programmes ( $\mathrm{I}-2$ years) whereas the two older cohorts consist of graduates from 4-year programmes (and in the case of the Medical study 6 years).

3. The unemployment rate might also vary within faculties. In case of the faculty Health, Medicine and Life Science the unemployment rate of Medical alumni is o\% for the two younger cohorts, whereas for Health and Life Science alumni the unemployment rate is between $2 \%$ and $3 \%$. relatively high unemployment rate of the youngest cohort (2009-2010) suggests. Considering the above figures, labour market participation is very high for all three cohorts of Maastricht University graduates.

Table 1

Unemployment ${ }^{1}$

\begin{tabular}{lccc}
\hline & \multicolumn{3}{c}{ \% unemployed } \\
& $2009-2010$ & $2005-2006$ & $2000-2001$ \\
\hline Business and Economics & 5 & 2 & 1 \\
Health, Medicine and Life Sciences & 3 & 2 & 1 \\
Arts and Social Sciences & 24 & 10 & $x$ \\
Psychology and Neuroscience & 11 & 4 & 4 \\
Law & 9 & 0 & 6 \\
Maastricht University & 8 & 3 & 2 \\
\hline
\end{tabular}

$1=$ too little information about the Faculty of Humanities and Sciences $x=$ too few cases

\section{Figure 1}

Trends in unemployment

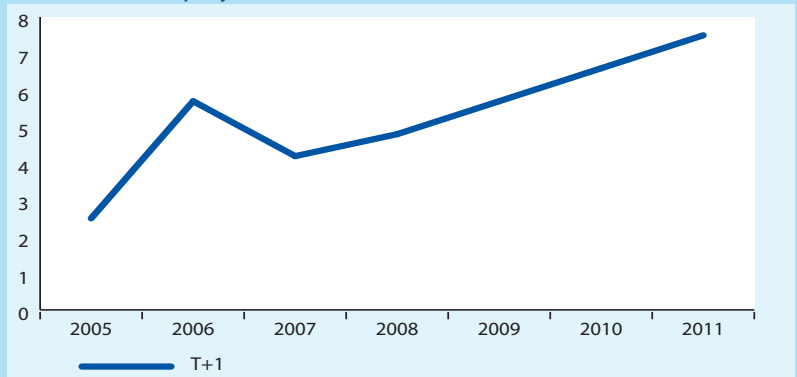

$1=$ the 2010 data are interpolated linearly $(T+1)$

\section{Trends in unemployment}

How has the economic crisis affected labour market opportunities of Maastricht University graduates since 2008? To get some insight into the possible answers to this question, we analyse briefly the average unemployment rate of Maastricht University graduates, as reported in surveys that were held each year between 2005 and 20II. For all seven years that these surveys were conducted, unemployment information for the three cohorts is available. For the two cohorts that are 6, respectively, II years on the labour market, no visible trend in unemployment rates can be observed. Particularly when comparing within cohorts over time, unemployment rates fluctuate trendless. In other words, the current economic crisis seems not to have an influence on the unemployment rate of Maastricht University alumni 6 to II years into their labour market career. However, a notable increase in unemployment rates can be observed when comparing those students who graduated one year prior to each survey (see Figure I). Although these figures need to be interpreted carefully, this suggests that Maastricht University graduates increasingly face difficulties when making the transition to the labour market. In Appendix 
A, these figures are further broken down by the various faculties.

\section{Job characteristics}

The match between graduates' education and the requirements of their job has important implications for the extent to which graduates can use their knowledge and skills. The quality of the education-job match is therefore positively related to job satisfaction, career opportunities and wages. Table 2 a presents the proportion of Maastricht University graduates with a good horizontal education-job match, that is, the percentage of alumni who work in jobs for which their own or a related field of study is required.

Table 2a

Horizontal match'

\begin{tabular}{lccc}
\hline & \multicolumn{3}{c}{$\begin{array}{c}\text { \% working in own or related } \\
\text { field of study } \\
\end{array}$} \\
& $2009-2010$ & $2005-2006$ & $2000-2001$ \\
\hline Business and Economics & 77 & 84 & 77 \\
Health, Medicine and Life Sciences & 87 & 84 & 90 \\
Arts and Social Sciences & 57 & 50 & $x$ \\
Psychology and Neuroscience & 89 & 80 & 80 \\
Law & 77 & 85 & 82 \\
Maastricht University & 80 & 81 & 82 \\
\hline
\end{tabular}

$1=$ too little information about the Faculty of Humanities and Sciences $\mathrm{x}$ : too few cases

The results are positive, with $81 \%$ of alumni from the 2005 2006 cohort, and $82 \%$ of the alumni from the $2000-2001$ cohort working in a good horizontal match. Also positive is that Maastricht University alumni appear to find jobs in their own field of study relatively fast: $80 \%$ of the alumni from the 2009-20I0 cohort that were employed, were working in a job that fit their field of education. But considerable differences can be observed between graduates from the various faculties. Graduates from the Faculty of Health, Medical and Life Sciences have above average figures for all three cohorts. However, an important side mark is that within this faculty, a strong distinction can be seen between the study of medicine and the studies of Health and Life sciences. Whereas by nature of their very specific education, Medical graduates are very well matched (between $92 \%$ for the youngest cohort and I0o\% for the two older cohorts), the figures are clearly lower for the graduates of Health and Life Science studies (2009-2010: 83\%; 2005-2006: 76\%). Also below average are the figures for the Faculty of Arts and Social Sciences where 50\% (2005-2006 cohort) to 57\% (cohort 2009-20I0) report a horizontal match. Moreover, $36 \%$ of the mismatched graduates from this faculty say that they were not able to find a job related to their field of study. ${ }^{4}$ This is well above the Maastricht University average

4. Other reasons for working outside the own domain are changes in interest or for instance the possibility to earn a higher salary. of $23 \%$, and only superseded by graduates from the Faculty of Psychology and Neuroscience. Of the horizontally mismatched students from this faculty, $45 \%$ reported that they could not find a job in their field of study. ${ }^{4}$

In addition to the horizontal match, the vertical match (i.e. whether graduates are working in a job for which a university degree is required) is an important indicator of the quality of the education-job match. Table $2 b$ shows that $86 \%$ of the graduates from the $2009-20$ Io cohort, $85 \%$ of the respondents who graduated in 2005-2006 and 89\% of the respondents who graduated in 2000-200I had an excellent vertical match between education and work at the time of the survey. There is, however, substantial variation between disciplines. 5 Psychology and Neuroscience, as well as Law graduates report excellent vertical matching rates, of about $90 \%$. Possible exception are law school alumni from the youngest cohort, of whom only $8 \mathrm{I} \%$ are employed in a university-level job. These outcomes are highly correlated with degree specificity as well as labour market conditions in the particular field. In all disciplines and for both cohorts, the percentage of graduates with an excellent vertical match increased markedly between the first and the current job.

\section{Table $2 b$}

Vertical match'

\begin{tabular}{|c|c|c|c|c|c|c|}
\hline & \multicolumn{3}{|c|}{$\begin{array}{c}\text { \% working at university } \\
\text { level or higher } \\
\text { first job }\end{array}$} & \multicolumn{3}{|c|}{$\begin{array}{l}\% \text { working at university } \\
\text { level or higher } \\
\text { current job }\end{array}$} \\
\hline & $\begin{array}{r}2009- \\
2010 \\
\end{array}$ & $\begin{array}{r}2005- \\
2006 \\
\end{array}$ & $\begin{array}{c}2000- \\
2001 \\
\end{array}$ & $\begin{array}{l}2009- \\
2010 \\
\end{array}$ & $\begin{array}{l}2005- \\
2006 \\
\end{array}$ & $\begin{array}{r}2000- \\
2001 \\
\end{array}$ \\
\hline Business and Economics & * & 77 & 79 & 87 & 85 & 88 \\
\hline $\begin{array}{l}\text { Health, Medicine and Life } \\
\text { Sciences }\end{array}$ & * & 71 & 80 & 86 & 81 & 90 \\
\hline Arts and Social Sciences & * & 65 & $x$ & 84 & 85 & $x$ \\
\hline Psychology and Neuroscience & * & 65 & 60 & 94 & 91 & 88 \\
\hline Law & * & 70 & 87 & 81 & 94 & 94 \\
\hline Maastricht University & * & 73 & 79 & 86 & 85 & 89 \\
\hline
\end{tabular}

$1=$ too little information about the Faculty of Humanities and Sciences * = For the cohort 2009-2010 (interviewed 1,5 year after graduation) no information on the first job is available. $\mathrm{x}=$ too few cases

\section{Income and working hours}

At the time of the survey, the median gross income of Maastricht University alumni of 2005-2006 is $€ 3600$ per month, and this rises to $€ 4500$ for the cohort of 2000-200I alumni (see Table 3). These numbers match the results of previous surveys. Also, income patterns across disciplines seem to remain more or less stable: Health, Medicine and

5. For the Faculty of Health, Medicine and Life Sciences a strong difference is again visible between the Medical Study (IOO\% of the graduates are matched perfectly with respect to this indicator) and Health and Life Sciences. Graduates of the latter studies are matched well in 74\% (2009-2010), 71\% (2005-2006) and 85\% (2000-200I) of the cases. 
Life Sciences alumni, Arts and Social Sciences alumni and Psychology and Neuroscience alumni have the lowest median income. Even after taking account of the relatively low number of working hours per week of Health, Medicine and Life Sciences alumni (especially for the 2000-200I cohort) substantial differences in salaries remain. ${ }^{6}$

When starting on the labour market, SBE alumni earn the highest salaries, with a median gross income of around $€ 2800$ per month. In contrast, graduates from the Arts and Social Sciences faculty earn a gross monthly median income of $€ \mathrm{I} 800$. With a median gross income of $€ 4400$ per month, SBE alumni earn most amongst the 2005-2006 cohort and after five further years in the labour market, they keep their top position with $€ 5500$. Maastricht University graduates from the two top income disciplines (Business and Economics and Law) report regular working hours per week between 36 and 40 . It is worth mentioning that these figures present contractual working hours excluding overtime. Actual working hours can deviate from these figures.

Table 3

Income and working hours ${ }^{1}$

\begin{tabular}{lcccccc}
\hline & \multicolumn{3}{c}{ gross income per month } & \multicolumn{3}{c}{ regular working hours } \\
& \multicolumn{3}{c}{ (median) } & \multicolumn{3}{c}{ per week } \\
& $2009-$ & $2005-$ & $2000-$ & $2009-$ & $2005-$ & $2000-$ \\
& 2010 & 2006 & 2001 & 2010 & 2006 & 2001 \\
\hline Business and Economics & 2.846 & 4.400 & 5.500 & 40.0 & 40.0 & 40.0 \\
Health, Medicine and Life & & & & & & \\
Sciences & 2.661 & 3.478 & 4.000 & 38.0 & 36.0 & 32.0 \\
Arts and Social Sciences & 1.800 & 3.044 & $x$ & 40.0 & 36.0 & x \\
Psychology and Neuroscience & 2.093 & 3.000 & 3.800 & 36.0 & 36.0 & 36.0 \\
Law & 2.393 & 3.625 & 4.500 & 40.0 & 40.0 & 38.0 \\
Maastricht University & 2.528 & 3.600 & 4.500 & 40.0 & 40.0 & 36.0 \\
\hline
\end{tabular}

$1=$ too little information about the Faculty of Humanities and Sciences $\mathrm{x}=$ too few cases

\section{Job satisfaction}

Job satisfaction of Maastricht University graduates is generally high. Of the 2009 -20I0 cohort, $80 \%$ of all employed alumni are satisfied with their jobs. Also, amongst the 20052006 cohort, $79 \%$ of alumni are satisfied with their jobs, and $84 \%$ of alumni are satisfied with their jobs amongst the 2000-200I cohort. The majority of Maastricht University alumni $(73 \%$ of the $2009-2010$ cohort, $70 \%$ of the 2005 2006 cohort and $65 \%$ of the $2000-200$ c cohort) also find that their current job offers good career opportunities (see Table 4).

6. The relative low median income is thereby strongly influenced by the income generated by alumni from Health and Life Sciences studies. Medical graduates have a) a higher starting salary and b) are the best paid alumni II years after graduation with a median income of Euro 6.00o. Due to the structure of their career paths, Medical alumni are also the group which displays the biggest income growth between six and eleven years after graduation.
Table 4

Job satisfaction, career opportunities

\begin{tabular}{lcccccc}
\hline & \multicolumn{3}{c}{ \% satisfied with job } & \multicolumn{3}{c}{ job offers good career } \\
& \multicolumn{3}{c}{$\begin{array}{c}2009- \\
\text { opportunities }\end{array}$} \\
& 2010 & $2005-$ & $2000-$ & $2009-$ & $2005-$ & $2000-$ \\
& 84 & 79 & 81 & 77 & 77 & 65 \\
\hline Business and Economics & & & & & & \\
Health, Medicine and Life & 80 & 84 & 85 & 77 & 69 & 66 \\
Sciences & 60 & 66 & $\mathrm{x}$ & 43 & 56 & $\mathrm{x}$ \\
Arts and Social Sciences & 79 & 70 & 87 & 74 & 48 & 70 \\
Psychology and Neuroscience & 73 & 78 & 84 & 73 & 69 & 65 \\
Law & 80 & 79 & 84 & 73 & 70 & 65 \\
Maastricht University & 800010 & 2006 & 2001 \\
\hline
\end{tabular}

$1=$ too little information about the Faculty of Humanities and Sciences $\mathrm{x}=$ too few cases

The question that provides information about career opportunities for the cohort 2009-2010 differs slightly from the question asked to respondents from the cohorts 2005-2006 and 2000-2001. Results have been made comparable.

\section{International orientation of Maastricht University and its} graduates

The international orientation of Maastricht University and the fact that English is the main language of instruction in many study programs, appears to be attracting an increasing number of international students for all faculties. Table sa shows the percentage of Maastricht University alumni of the various cohorts who are currently working inside and outside the Netherlands, split by faculty. For Maastricht University as a whole, $20 \%$ of the alumni of the 2005-2006 cohort are working in European countries other than the Netherlands, and $3 \%$ are working outside of Europe. Of the youngest cohort, almost one-third has found employment outside the Netherlands, also mostly in European countries. These numbers include foreign students who returned to their home country after graduation.

Considerable variation exists between the faculties. ${ }^{7}$ Graduates from the School of Business and Economics are particularly internationally active, closely followed by those of the Faculty of Psychology and Neurosciences. But alumni from the Faculty of Arts and Social Sciences stand out most notably. Of the $2005-2006$ cohort, $39 \%$ of the students were working in countries other than the Netherlands, which was relatively high. Of the youngest cohort however, no less than $7 \mathrm{I} \%$ of the alumni from this faculty where working abroad. These figures thus indicate that for alumni from the Faculty of Arts and Social Sciences, international labour markets are now more important than the Dutch labour market. The figures also show that although there exist large differences between faculties in the extent to which graduates pursue an international career, the share of internationally active

7. In case of the Law Faculty, considerable variation exists also within the Faculty between graduates of Dutch Law (Dutch labour market oriented) and graduates of International Law (European labour market oriented). 
graduates has increased for all but one faculty between $200 \mathrm{I}$ and 20II.

Asked to what extent the education received at Maastricht University prepared them for the international labour market, $51 \%$ of the $2005-2006$ cohort and $42 \%$ of the 2000-200I cohort responded that they felt prepared to a high or very high extent. Here too, variation exists between the faculties. Table sb illustrates the relationship between feeling prepared to work abroad and actually working abroad. According to this figure, the School of Business and Economics is the most internationally oriented, with $79 \%$ of 2005-2006 graduates feeling prepared for the international labour market and 39\% actually working outside the Netherlands.

It is noteworthy that most faculties seem to improve the extent to which they prepare students for an international career. Compared to the 2000-200I cohort alumni from the 2005-2006 cohort more often feel well prepared for the international labour market.

Table 5a

Percentage currently working abroad ${ }^{1}$

\begin{tabular}{|c|c|c|c|c|c|c|c|c|c|}
\hline & \multicolumn{3}{|c|}{ 2009-2010 } & \multicolumn{3}{|c|}{ 2005-2006 } & \multicolumn{3}{|c|}{$2000-2001$} \\
\hline & NL & EU & Other & NL & EU & Other & NL & EU & Other \\
\hline Business and Economics & 52 & 46 & 2 & 61 & 34 & 5 & 76 & 21 & 3 \\
\hline $\begin{array}{l}\text { Health, Medicine and Life } \\
\text { Sciences }\end{array}$ & 90 & 9 & 1 & 95 & 3 & 2 & 94 & 2 & 4 \\
\hline Arts and Social Sciences & 29 & 71 & 0 & 61 & 34 & 5 & $\mathrm{x}$ & $x$ & $x$ \\
\hline $\begin{array}{l}\text { Psychology and } \\
\text { Neuroscience }\end{array}$ & 69 & 31 & 0 & 80 & 15 & 4 & 96 & 4 & 0 \\
\hline Law & 81 & 15 & 4 & 91 & 8 & 2 & 94 & 2 & 5 \\
\hline Maastricht University & 67 & 30 & 3 & 76 & 20 & 3 & 88 & 9 & 3 \\
\hline
\end{tabular}

$1=$ too little information about the Faculty of Humanities and Sciences

$x=$ too few cases

Table $5 b$

Percentage of alumni feeling well prepared for international labour market and percentage working abroad'

\begin{tabular}{|c|c|c|c|c|c|c|}
\hline & \multicolumn{2}{|c|}{$2009-2010$} & \multicolumn{2}{|c|}{$2005-2006$} & \multicolumn{2}{|c|}{$2000-2001$} \\
\hline & $\begin{array}{c}\text { well } \\
\text { prepared }\end{array}$ & $\begin{array}{l}\text { working } \\
\text { abroad }\end{array}$ & $\begin{array}{c}\text { well } \\
\text { prepared }\end{array}$ & $\begin{array}{l}\text { working } \\
\text { abroad }\end{array}$ & $\begin{array}{c}\text { well } \\
\text { prepared }\end{array}$ & $\begin{array}{l}\text { working } \\
\text { abroad }\end{array}$ \\
\hline $\begin{array}{l}\text { Business and } \\
\text { Economics }\end{array}$ & * & 48 & 79 & 39 & 75 & 24 \\
\hline $\begin{array}{l}\text { Health, Medicine } \\
\text { and Life Sciences }\end{array}$ & * & 10 & 29 & 5 & 27 & 6 \\
\hline $\begin{array}{l}\text { Arts and Social } \\
\text { Sciences }\end{array}$ & * & 71 & 36 & 39 & $x$ & \\
\hline $\begin{array}{l}\text { Psychology and } \\
\text { Neuroscience }\end{array}$ & * & 31 & 27 & 20 & 42 & \\
\hline Law & * & 19 & 36 & 9 & 31 & 0 \\
\hline Maastricht & * & 33 & 51 & 24 & 42 & 12 \\
\hline
\end{tabular}

University

$1=$ too little information about the Faculty of Humanities and Sciences

* = For the cohort 2009-2010 (interviewed 1,5 year after graduation) no information is available.

$x=$ too few cases

\section{Satisfaction with study at Maastricht University}

Finally, alumni were asked to reflect on their time at Maastricht University and assess which choices they would make in retrospect. In the 2009-20I0 cohort, $80 \%$ of the alumni would again choose the exact same study at Maastricht University. For the cohorts that graduated in the academic years 2005-2006 and 2000-200I, these figures where $72 \%$ and $75 \%$, respectively. Table 6 presents the survey results for the three cohorts by faculty. ${ }^{8}$

\section{Table 6}

Percentage of alumni who would again choose to study at Maastricht University

\begin{tabular}{lccc}
\hline & $2009-2010$ & $2005-2006$ & $2000-2001$ \\
\hline Business and Economics & 84 & 78 & 81 \\
Health, Medicine and Life Sciences & 78 & 67 & 72 \\
Arts and Social Sciences & 69 & 62 & 79 \\
Psychology and Neuroscience & 77 & 68 & 62 \\
Law & 85 & 72 & 79 \\
Maastricht University & 80 & 72 & 75 \\
\hline
\end{tabular}

$1=$ too little information about the Faculty of Humanities and Sciences

In line with these findings, $77 \%$ of the respondents report that their study at Maastricht University is still (very) useful for their current job. These results are consistent across faculties and cohorts.

Even five and ten years after graduation, the bond between Maastricht University and its alumni is still strong. As part of the survey, alumni were asked whether Maastricht University could contact them to ask them to give a lecture or a presentation, to act as contact person in their company should internships become available there, or to act as a 'mentor' for current students. Six out of ten respondents indicated that they would like to become more involved in at least one of these Maastricht University alumni networks.

8. Within the Faculty of Health, Medicine and Life Sciences, graduates of the Medical studies are significantly more satisfied with their study choice in retrospect. $60 \%-65 \%$ of the graduates of Health and Life Science would again choose the same study at Maastricht University compared to $80 \%-90 \%$ of the Medical graduates. 


\section{Appendix A}

Table 7

Trends in unemployment ${ }^{1}$

\begin{tabular}{|c|c|c|c|c|c|c|c|}
\hline & 2005 & 2006 & 2007 & 2008 & 2009 & $2010^{2}$ & 2011 \\
\hline & $\mathrm{T}+1$ & $\mathrm{~T}+1$ & $\mathrm{~T}+1$ & $\mathrm{~T}+1$ & $\mathrm{~T}+1$ & $\mathrm{~T}+1$ & $\mathrm{~T}+1$ \\
\hline & 2003-2004 & $2004-2005$ & $2005-2006$ & 2006-2007 & $2007-2008$ & 2008-2009 & 2009-2010 \\
\hline Business and Economics & 2,8 & 2,7 & 2,3 & 4,2 & 5,7 & 5,3 & 4,9 \\
\hline Health and Life Sciences & 1,1 & 6,1 & 5,3 & 4,2 & 0,0 & 2,2 & 4,4 \\
\hline Medicine & 0,0 & 0,0 & 2,1 & 2,8 & 0,0 & 0,0 & 0,0 \\
\hline Arts and Social Sciences & 8,3 & 25,0 & 11,1 & 13,8 & 18,5 & 21,2 & 23,9 \\
\hline Psychology and Neuroscience & 7,5 & 14,9 & 8,1 & 0,0 & 6,1 & 8,75 & 11,4 \\
\hline Law & 3,0 & 7,0 & 2,5 & 5,8 & 6,0 & 7,4 & 8,8 \\
\hline \multirow[t]{4}{*}{ Maastricht University } & 2,5 & 5,7 & 4,2 & 4,8 & 5,7 & 6,6 & 7,5 \\
\hline & 2006 & 2007 & 2008 & 2009 & 2010 & 2011 & 2012 \\
\hline & $\mathrm{T}+5$ & $\mathrm{~T}+5$ & $\mathrm{~T}+5$ & $\mathrm{~T}+5$ & $\mathrm{~T}+5$ & $\mathrm{~T}+5$ & $\mathrm{~T}+5$ \\
\hline & $1999-2000$ & $2000-2001$ & $2001-2002$ & $2002-2003$ & 2003-2004 & 2004-2005 & $2005-2006$ \\
\hline Business and Economics & 4,5 & 0,7 & 0,5 & 3,2 & 2,2 & 5,4 & 1,9 \\
\hline Health and Life Sciences & 0,6 & 2,0 & 2,1 & 3,4 & 2,4 & 3,2 & 3,0 \\
\hline Medicine & 0,0 & 1,4 & 1,3 & 0,0 & 0,0 & 1,5 & 0,0 \\
\hline Arts and Social Sciences & - & - & - & - & - & 3,8 & 10,1 \\
\hline Psychology and Neuroscience & 3,7 & 0,0 & 5,7 & 1,9 & 7,0 & 10,3 & 4,2 \\
\hline Law & 0,0 & 1,0 & 0,0 & 1,2 & 4,3 & 3,8 & 0,0 \\
\hline \multirow[t]{4}{*}{ Maastricht University } & 2,4 & 1,1 & 1,3 & 2,3 & 2,5 & 4,4 & 2,7 \\
\hline & 2006 & 2007 & 2008 & 2009 & 2010 & 2011 & 2012 \\
\hline & $\mathrm{T}+10$ & $\mathrm{~T}+10$ & $\mathrm{~T}+10$ & $\mathrm{~T}+10$ & $\mathrm{~T}+10$ & $\mathrm{~T}+10$ & $\mathrm{~T}+10$ \\
\hline & 1994-1995 & 1995-1996 & 1996-1997 & 1997-1998 & 1998-1999 & $1999-2000$ & $2000-2001$ \\
\hline Business and Economics & 0,8 & 1,5 & 0,9 & 0,0 & 3,0 & 2,8 & 0,9 \\
\hline Health and Life Sciences & 2,4 & 2,0 & 2,2 & 0,9 & 0,8 & 1,8 & 0,9 \\
\hline Medicine & 0,0 & 1,9 & 2,3 & 0,0 & 0,0 & 2,6 & 1,8 \\
\hline Arts and Social Sciences & - & - & - & - & - & - & - \\
\hline Psychology and Neuroscience & - & - & - & 0,0 & 0,0 & 0,0 & 3,8 \\
\hline Law & 4,6 & 2,4 & 1,2 & 0,0 & 1,5 & 0,0 & 6,1 \\
\hline Maastricht University & 2,0 & 2,0 & 2,0 & 0,3 & 1,7 & 2,0 & 2,0 \\
\hline
\end{tabular}

$1=$ too little information about the Faculty of Humanities and Sciences

$2=$ the 2010 data are interpolated linearly $(T+1)$

$\mathrm{x}=$ too few cases 


\section{Colofon}

Copyright (C) 2012, Research Centre for Education and the Labour Market, Maastricht. No part of this publication may be reproduced in any way without prior permission of the Director of ROA.

Research Centre for Education and the Labour Market

P.O. Box 616

6200 MD Maastricht

The Netherlands

secretary-roa-sbe@maastrichtuniversity.nl

www.roa.nl

Maastricht University

School of Business and Economics

\section{Layout}

ROA secretary, Maastricht

November 2012 
Researchcentrum voor Onderwijs en Arbeidsmarkt

Postbus 616

6200 MD Maastricht

$\mathrm{T}+31433883647$

F +31 433884914

secretary-roa-sbe@maastrichtuniversity.nl

www.roa.nl

Maastricht University

School of Business and Economics 